Abstracta Iranica Abstracta Iranica

Revue bibliographique pour le domaine irano-aryen

Volume 27 | 2006

Comptes rendus des publications de 2004

\title{
" Farghana under the Samanids (According to the data of numismatics) ». Iran, 42 (2004), pp. 119-129.
}

\section{David Durand-Guédy}

\section{OpenEdition}

1 Journals

\section{Édition électronique}

URL : http://journals.openedition.org/abstractairanica/6018

DOI : 10.4000/abstractairanica.6018

ISSN : 1961-960X

Éditeur :

CNRS (UMR 7528 Mondes iraniens et indiens), Éditions de l'IFRI

\section{Édition imprimée}

Date de publication : 15 mai 2006

ISSN : 0240-8910

\section{Référence électronique}

David Durand-Guédy, « «Farghana under the Samanids (According to the data of numismatics) ». Iran, 42 (2004), pp. 119-129. », Abstracta Iranica [En ligne], Volume 27 | 2006, document 203, mis en ligne le 02 janvier 2007, consulté le 25 septembre 2020. URL : http://journals.openedition.org/ abstractairanica/6018; DOI : https://doi.org/10.4000/abstractairanica.6018

Ce document a été généré automatiquement le 25 septembre 2020.

Tous droits réservés 


\title{
« Farghana under the Samanids (According to the data of numismatics) ». Iran, 42 (2004), pp. 119-129.
}

\author{
David Durand-Guédy
}

Contribution érudite à l'histoire politique du Farghana sous domination samanide d'après les données numismatiques. L'A. étudie successivement la période durant laquelle le Farghana était une province autonome soumise à une branche de la famille samanide (jusqu'en 816), puis la période durant laquelle le Farghana fut intégré à l'Etat samanide et placé sous le contrôle de gouverneurs souvent turcs (jusqu'en 991). L'A. fait la synthèse de la vaste bibliographie en russe sur le sujet, en particulier les travaux de Davidovich et de Kochnev, en apportant quelques éléments nouveaux. Signalons aussi, du même A., la parution d'un court article sur une émission monétaire de la période mongole près de la ville de Taraz. Cf. "The newly discovered Chaghatayid mint of Kenjek (Kenchek) », R.N. (Paris), vol. 160 (2004), pp. 367-74.

\section{INDEX}

Thèmes : 4.2.2. Asie centrale 
AUTEURS

DAVID DURAND-GUÉDY

IFRI - Téhéran 